\title{
HUMAN DISEASE IN RIBEIRA VALLEY, BRAZIL CAUSED BY CARAPARU, A GROUP C ARBOVIRUS - REPORT OF A CASE
}

\author{
Lygin Busch IVERSSON (1); Améliz P. A. TRAVAssos DA ROSA (2); Terezinha Lisieux M.
} COLMBRA (3); Ivani Bisordi FERRgira (3) \& Flza da Silva NASSAR (3)

\section{S U M M A R Y}

The clinical and laboratory data of a disease in a resident of Ribeira Valley, São Paulo State, southeastern Brazil, caused by an agent close or identical to Caraparu, a Group C arbovirus, was described.

Although there is evidence of an intensive circulation of several arboviruses in the area, no diagnosis of human disease by these agents has been made, except the encephalitis cases caused by Rocio virus during an epidemic in 1975-1977.

An antigenic difference between Caraparu strains isolated in São Paulo and in Pará States and a close antigenic relationship between Caraparu strain from São Paulo and Bruconha virus were suggested by the serological tests.

KEY WORDS: Arbovirus Caraparu - human disease.

\section{N T ROD U CTIO N}

In 1975 an epidemic of encephalitis caused by a newiy recognized flavivirus, ROCIO 25,15 suddenly struck on southeastern Brazil, in an area that includes the region of Ribeira Valley. Since then a number of studies have been carried out there in an involved in their persistence $2,3,4,7,8,9,11,12,13,14,15,16,17,19,20,21$.

Results of the studies indicated the presence of many arboviruses known to be pathogenic for men. Among virus isolations from mosquitoes, sentinel mice and hamsters, birds, bats and humans, 13 arboviruses were identified, of which three were known human pathogens: eastern equine encephalitis, Rocio and Caraparu viruses 16,2,3,4. Serological surveys have also suggested the probable circulation in man of Mucambo and SP AN 50783 (Venezuelan equine encephalitis complex), Ilheus and $\mathrm{St}$ Louis encephalitis viruses $11,12,13,14$.
However, only cases of encephalitis has an arbovirus etiology been suspected and in many patients this has not been confirmed.

We present here a case of febrile illness in a man that was living in the Ribeira Valley. The serologic diagnosis indicates that the etiologic agent, a virus close to or identical to $\mathrm{Ca}$ ráparu virus, caused human disease in this area.

\section{MATERIAI AND METHODS}

\section{Characteristics of the area}

The Ribeira Valley $\left(24^{\circ}-25^{\circ} 16^{\prime} \mathrm{S}, 46^{\circ} 50^{\prime} \rightarrow\right.$ $49^{\circ} 20^{\circ}$ ) is located in the south of São Paulo State, southeastern Brazil (figure 1). About $58 \%$ of the area is still covered extensively by forests and has a highly humid tropical clims. te 2 .

(1) Department of Epidemiology, Public Fealth School, University of São Paulo, Av, Dr. Arnaldo, 715. CreP 01255. Såo Paulo, Bravill.

(2) Evandro Chagas Institute, F.S.E.S.P., Belém, Parḱ, Brazil.

(3) Adolfo Lutz Institute, Health Department of São Paulo, Brazil. 
IVERSSON, L. B.; TRAVASSOS DA ROSA, A. P. A.; COMMBRA, T. L. M.; FERREIRA, I. B. \& NASSAR, E. da S. - HU man disease in Ribeira Valley. Brazil caused by Caraparu, a group $C$ arbovirus - Report of a case. Rev. Inst. Med. trop. Săo Paulo, 29:112-117, 1987.

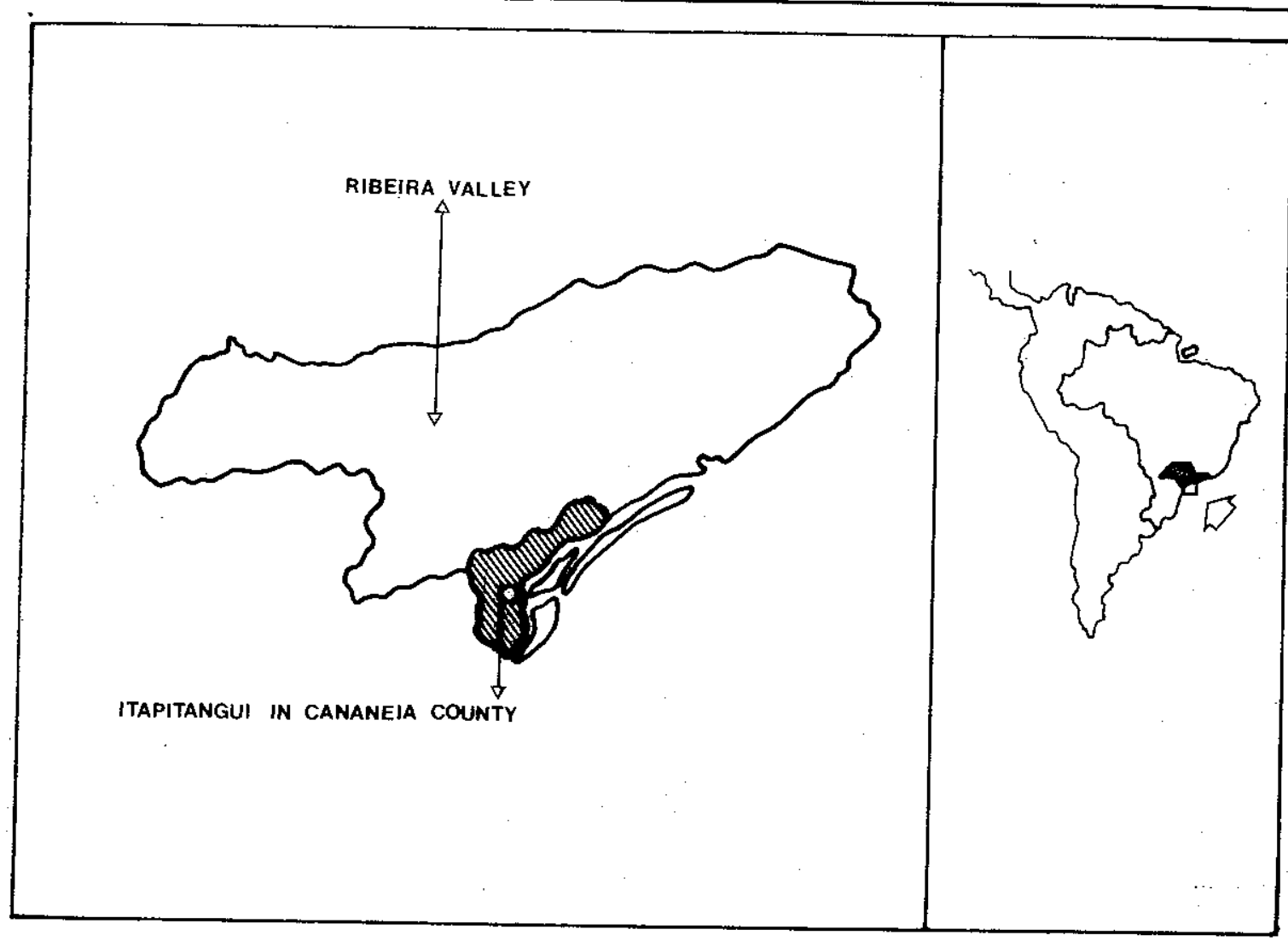

Fig. 1 - Geograhic position of the Ribeira Valley and the Cananeia Country.

The local population, 243,290 inhabitants in $1980^{10}$, work mostly in agriculture, fishing and lumbering and has the lowest income of São Paulo State 22 .

\section{Case report}

A 28-year-old man developed high fever $\left(38.5^{\circ}-39^{\circ} \mathrm{C}\right)$ chills, severe headache, myalgia and prostaction. Within 48 hours, during which he was treated with bed rest and aspirin, the symptoms disappeared completely. Since the patient was a biologist who had lived in the last nine months in a town of the Ribeira Valley and was working with an entomological team conducting studies in the forested area, the diagnosis of an arbovirus infection was suspected. During the two weeks before the onset of the disease he had been working in a small farm in Itapitangui, Cananeia, a coastal district (figure 1). From Monday afternoom until Wednesday, a team of six men usually carried out catching of mosquitoes using hu- man bait. None of the other workers became sick.

Serum samples were collected from the patient on the second and 15th days after the first symptoms and tested by hemagglutination-inhibition (HI), according to technique described by SHOPE 23, and by complement fixation (CF), according to methods reported by CASALS ${ }^{51}$, against the antigens of eastern equine encephalitis (SP An 14723), western equine encephalitis (Tr 25717) Mucambo (SP An 15600) SP an 50783 (new variant of subtype I of VEE complex) Rocio (SP H 34675) Ilheus (Be H 7445) St Louis encephalitis (Be An 11916) dengue-2 ( $\operatorname{Tr} 1751$ ), yellow fever (Asibi and 17D) and Caraparu (SP An 26550, isolated in São Pau1o State and the prototype strain, Be An 3994, isolated in Pará State).

After a serological conversion to Caraparu virus was observed, other members of Group C, known to occur in Brazil (Apeu-Be An 848, 
IVERSSON, L. B.; TRAVASSOS DA ROSA, A. P. A.; COIMBRA, T. L. M.; FERREIRA, I. B. \& NASSAR, E. da S. - Fuman disease in Ribeira Valley, Brazil caused by Caraparu, a group $C$ arbovirus - Report of a case:- hev. Inst. Med. trop. São Paulo, 29:112-117, 1987.

Itaqui-Be H 1779, Marituba - Be An 15, Murutucu - Be An 974, Nepuyo - TRVL 18462, Oriboca - Be An 17 and Bruconha, a newly recognized Group $\mathbf{C}$ virus isolated in Ribeira Valley from Culex (Melanoconion) sp. mosquitoes ${ }^{2,4}$ ) were tested by $\mathrm{HI}, \mathrm{CF}$ and neutralization (N) tests. The last one was performed using suckling mice, according to a technique described by CASALS 51 .

A serum collected eight months after the illness was also tested for antibody to antigens of Group C. The neutralization test to Bruconha virus was performed only on this serum. The acute serum sample was not available when we have received this virus from the laboratory of Division of Vector-Borne Viral Diseases, C.D.C., U.S.A.

Isolation of the virus was not attempted since the acute serum samples was not preserved at $-70^{\circ} \mathrm{C}$ after collection.

\section{RESULTS}

A serological conversion to Caraparu (SP An 26550) and Bruconha viruses was apparent from the results of $H I$ test presented on table 1. $\mathbf{N}$ test have confirmed the serological conversion to Caraparu (SP An 26550, Be An 3994) and Apeu (Be An 848) viruses, with highest. titers to SP An 26550 (table 3). The serum sam ple collected 8 months after the disease has presented a long neutralization index of 4.8 to Bruconha virus.

CF antibodies, in low titers, were present on the acute and convalescent sera with highest. titer to Bruconha virus. (Table 2).

T A B L E I

Results of hemagglutination - inhlbition (HI) teste with paired human sera and group C prototype strains

\begin{tabular}{|c|c|c|c|c|c|c|c|c|c|}
\hline \multirow[b]{2}{*}{ Serum } & \multirow[b]{2}{*}{$\begin{array}{l}\text { Bruconisa } \\
77 \text { V14814 }\end{array}$} & \multirow[b]{2}{*}{$\begin{array}{c}\text { Caraparu } \\
\text { SP An } 26550\end{array}$} & \multirow[b]{2}{*}{$\begin{array}{l}\text { Caraparu } \\
\text { Be An } 3994\end{array}$} & \multicolumn{2}{|c|}{ Antigen (4u) } & \multirow[b]{2}{*}{$\begin{array}{c}\text { Apeú } \\
\text { An } 848\end{array}$} & \multirow[b]{2}{*}{$\begin{array}{c}\text { Oriboca } \\
\text { An } 17\end{array}$} & \multirow[b]{2}{*}{$\begin{array}{c}\text { Murutucú } \\
\text { An } 974\end{array}$} & \multirow[b]{2}{*}{$\begin{array}{l}\text { Nepuyo } \\
\text { An 10709 }\end{array}$} \\
\hline & & & & $\begin{array}{l}\text { Itsqui } \\
\text { An } 12797\end{array}$ & $\begin{array}{c}\text { Marituba } \\
\text { An } 15\end{array}$ & & & & \\
\hline Bruconha & $640^{*}$ & 640 & 640 & 160 & 160 & 320 & 80 & 160 & 320 \\
\hline Caraparu & & & & & & & & & \\
\hline SP An 26550 & 640 & 640 & 640 & 80 & 80 & 160 & 40 & 80 & 160 \\
\hline \multicolumn{10}{|l|}{ Caraparu } \\
\hline Be An 3944 & 320 & 320 & 1.280 & & & & & & \\
\hline Itaqui & $<20$ & & & 160 & & & & & \\
\hline Marituba & 80 & & & & 320 & & & & \\
\hline Apeú & 40 & & & & & 160 & & & \\
\hline Oriboca & $<20$ & & & & & & 160 & & \\
\hline Murutucú & 80 & & & & & & & 160 & \\
\hline Nepuyo & 40 & & & & & & & & 320 \\
\hline St & $<10$ & $<10$ & $<10$ & $<10$ & $<10$ & $<10$ & $<10$ & $<10$ & $<10$ \\
\hline S2 & 40 & 40 & 20 & $<10$ & $<10$ & 20 & $<10$ & $<10$ & $<10$ \\
\hline \$3 & 40 & 40 & $<20$ & & & & & & \\
\hline Control & $<20$ & $<20$ & $<20$ & $<20$ & $<20$ & $<20$ & $<20$ & $<20$ & $<20$ \\
\hline $\begin{array}{l}\text { Blank indic } \\
\text { * Titer of } \mathrm{HI}\end{array}$ & $\begin{array}{l}\text { not tested } \\
\text { ibody }\end{array}$ & & $\begin{array}{l}\mathrm{Si}- \\
\mathrm{S2}- \\
\mathrm{S3}-\end{array}$ & $\begin{array}{l}\text { rum of } p \\
\text { rum of } p \\
\text { rum of } p\end{array}$ & $\begin{array}{l}\text { atient collec } \\
\text { atient collec } \\
\text { atient collec }\end{array}$ & $\begin{array}{l}\mathrm{d} \text { on } 12 / \\
\mathrm{d} \text { on } 12 \\
\mathrm{~d} \text { on } 8\end{array}$ & $\begin{array}{l}6 / 83 \\
9 / 83 \\
/ 84\end{array}$ & & \\
\hline
\end{tabular}

\section{DISCUSSION}

The serological results indicated a recent infection caused by Caraparu virus or a virus closely related.

Our current knowledge about natural cycles of Group $\mathrm{C}$ bunyavirus isolated in neotropical region, particularly in northern Brazil 1 , points out that they circulate among rodents, marsupials and eventually humans, transmitted by mosquitoes of genus Culex specially Culex (Melanoconion). Ribeira Valley presents a rich fauna of these small vertebrates and mosquitoes. Cx. (Melanoconion) was one of predominant species in longitudinal studies carried out both in extra and intradomiciliary environment in localities where encephalitis cases have occurred 7,8 .

Thus, the occurrence of disease caused by Group $\mathbf{C}$ virus in a man with high exposition 
IVGRSSON, L. B.; TRAVASSOS DA ROSA, A. P. A.; COIMBRA, T. L. M.; FERREIRA, I. B. \& NASSAR, E. da S. - Human disease in Ribeira Valley. Brazil caused by Caraparu, a group $C$ arbovirus - Report of a case. Rev. Inst. Med. trop. São Paulo, 29:112-117, 1987.

T A B I E II

Results of fixation complement (FC) tests with paired human sera and Bruconha and Caraparu (SP AN 26550) antigens

\begin{tabular}{ccc}
\hline Serum & Bruconha & $\begin{array}{c}\text { Antigens } \\
\text { Caraparu } \\
\text { (SP An 30256) }\end{array}$ \\
\hline S1 & $8 / 32^{*}$ & $8 / 8$ \\
S2 & $16 / 32$ & $8 / 8$ \\
S3 & $<8 / 32$ & $<8 / 8$ \\
Bruconha & $32 / 256$ & \\
Caraparu & & $8 / 64$ \\
(SP An 26550) & & 8 \\
\hline
\end{tabular}

* serum titer/antigen titer

Si serum sample collected on 12-16-83

S2 serum sample collected on 12-29-83

S3 serum sample collected on $8-9.84$

$$
\text { T A B L E III }
$$

Results of neutralization test with paired human sera and Caraparu and Apeu viruses

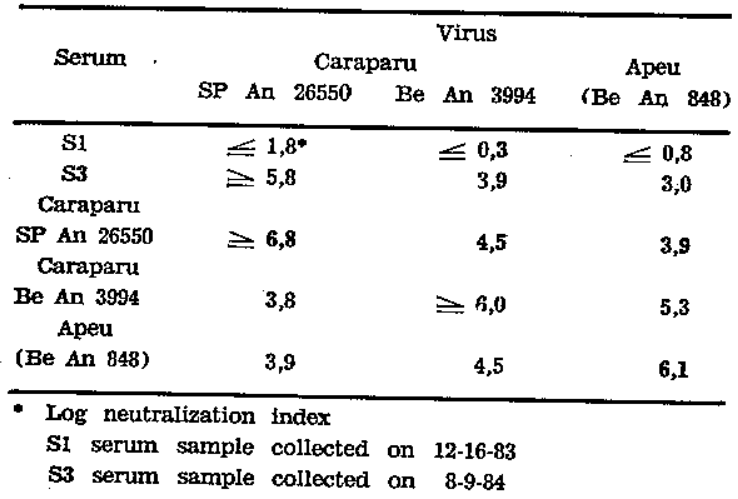

to wild anthropophilic mosquitoes was not surprising. In prior serological survey on 83 heal. thy road workers that were living in the region close to the forest, 12 out of them presented Caraparu IH antibodies 12. Even in healthy women and children that always lived in small towns of the region, $\mathbf{N}$ antibodies to Caraparu were detected, suggesting eventual urban trans. mission of this virus 13,14. But, until now, this diagnosis has not been made by the local physicians, either due to the absence of laboratory facilities for a rapid diagnosis or because the arbovirus etiology was remembered only in severe diseases with central nervous systern disturbances.

The clinical symptoms observed in the pa. tient were similar to those mentioned in cases where the Caraparu virus was isolated from blood during the viremic phase ${ }^{18}$.
Serologic results with patient sera are consistent with the antigenic behavior of Caraparu virus which is closely related to Apeu virus in $\mathrm{HI}$ and $\mathbf{N}$ tests 6,24 .

The results also suggested a close antigenic relationship between Caraparu, Strain isolated in São Paulo, and Bruconha virus. When the latter was identified as a newly Group C virus, the Caraparu prototype (Be An 3994) was used, among other Group C prototype strains, for its characterization ${ }^{4}$. But the HI and $\mathbf{N}$ tests processed on sera of the patient (Tables 1 and 3) showed an antigenic difference between Caraparu strains from Belém and São Paulo. A more detailed study about the antigenic relationships between SP An 26550 and Bruconha viruses seems called for. Serologic studies of human population are also warranted for Bruconha virus because the possible role of this virus as an human pathogen.

\section{RESUMO}

Caso de moléstia humana causada por arbovirus do Grupo C, Caraparu, na região do Vale do Ribeira, São Paulo, Brasil.

Relatam-se os dados clínicos e laboratoriais de um caso de moléstia humana causada por vírus idêntico ou antigenicamente muito relacionado ao arbovirus do Grupo C Carapari, em um morador da região do Vale do Ribeira, Estado de São Paulo, sudeste do Brasil. O fato apresenta interesse médico sanitário pois embora existam evidências da presença de inúmeros arbovírus na área, os únicos casos comprovados de doença por esses agentes foram os de encefalite pelo vírus Rocio durante $\mathbf{a}$ epidemia ocorrida em 1975-1977. Os resultados dos testes sorologicos sugerem diferença antigênica entre as cepas de vírus Caraparu isoladas nos Estados de São Paulo e Pará e pro. ximidade antigênica entre a cepa de Caraparu de São Paulo e o vírus Bruconha.

\section{REFBRENCES}

1. BERGE, T. O., ed. - International catalogue of arboviruses. 2nd. ed. Washington, Usdhew, 1975. (Publ. 75-8301).

2. CALISHER, C. H.; LOPES, O. DE S.; COIMBRA, T. I. M.; FRANCY, D. B.; JAKOB, W. L. \& MONATH, T. P. - Isolations of new alpha and bunyaviruses of 
IVERSSON, L. B.; TRAVASSOS DA ROSA, A. P. A.; COIMBRA, T. L. M.; FERREIRA, I. B. \& NASSAR, E. da S. - Human disease in Ribeira rnnlev Brazil caused by Caraparu, a group $\mathrm{C}$ arbovirus - Report of a case. Rev. Inst. Med. trop. Sāo Panlo, 29:112-117, 1987.

southern Brazil: Proposed reclassification of serogroups. In: Simpósio Internacional sobre Arbovirus dos Trópicos e Febres Hemorrágicas, Belém, 1980. Rio de Janeiro, Academia Brasileira de Ciências, 1982. p. $411-417$.

3. CALISHER, C. H.; KINNEY, R. M.; LOPES, O. DE S.; TRENT, D. W.; MONATH, T. P. \& FRANCX, D. B. - Identification of a new Venezuelan equine encephalitis viris from Bravil. Amer. J. trop. Med. Hyg. 31: $1260-1272,1982$.

4. CALISHER, C. H.; COIMBRA, T. L. M.; LOPES, O DE S.; MUTH, D. J.; SACCHETTA, L. DE A.; FRANCY, D. B.; LAZUICK, J. S. \& CROPP, C. B. - Identification of new guama and group $C$ serogroup bunyaviruses and an ungrouped virus from southern Brazil. Amer. J. trop. Med. Hyg., 32: 424-431, 1983.

5. CASALS, J. - Immunological techniques for animal viruses. In: MORAMOROSH, k. \& KOPROWSKI, H. - Methods in virology. New York, Academic Press, 1967. y. 3. p. $175-181$.

6. CASALS, J. \& WHTTMAN, L. - Group $C$ a new serological group of hitherto indescribed arthropod. bome virus immunological studies. Amer. J. trop. Med. Hyg., 10: 250-258, 1961.

7. FORATTINI, O. P.; GOMES, A. DE C.; GALATI, E. A. B.; RABELLO, E. X. IVERSSON, L. B. - Estudos ecológicos sobre mosquitos Culiciáae no sistemo Serra: do Mar, Brasil. 1. Observações no ambiente extradomiciilar. Rev. Saúde públ. (S. Paulo), 12: 297-325, 1978.

8. FORATTINI, O. P.; GOMES, A. DE C.; GALATI, E. A. B.; RABELLO, E. X. \& IVERSSON, t, B. - Estudos ecológicos sobre mosquitos Culicidae no sistema Serra do Mar. 2. Observaçōes no ambiente domiciliar. Rev. Saúde públ. (S. Paulo), 12: 476-496, 1978.

9. FORATTINI, O. P.; GOMES, A. DE C.; SANTOS, J. L. F.; GALATI, E. A. B.; RABELLO, E. X. \& NATAL, D. - Observaçöes sobre atividade de mosquitos Culicidae em mata residual no Vale do Ribeira, $S$. Paulo, Brasil. Rev. Saúde públ. (S. Paulo), 15: 557-586, 1981.

10. FUNDAÇAO I.B.G.E. - Sinopse preliminar do censo temográfico. Rio de Janeiro, 1981. 9.o Recenseamento Geral do Brasil. V. 1, n.o 16.

11. IVERSSON, L. B.; TRAVASSOS DA ROSA, A. P. A \& TRAVASSOS DA ROSA, J. - Estudos sorológicos para pesquisa de anticorpos de arbovirus em populaçăo humana da região do Vale do Ribeira. II. Inquérito em pacientes do Hospital Rogional de Pariquera-Açu, 1980. Rev. Saúde públ. (S. Paulo), 15: 587-602, 1981.

12. IVERSSON, L. B.; TRAVASSOS DA ROSA, A. P. A.; TRAVASSOS DA ROSA, J.; ELEUTERIO, G. C. \& PRADO, J. A. - Estudos sorológicos para pesquisa de anticorpos de arbovirus em populaçăo humana da regiăo do Vale do Ribeira. I. Seguimento sorológico de grupo populacional residente em ambiente silvestre.
In: Simpósio Internseional de arbovirus dos trópicos e feures hemorrágicas, Belém, 1980. Rio de Janeiro, Academia Brasileira de Ciências, 1982, p. 229-243.

13. IVERSSON, L. B.; TRAVASSOS DA ROSA, A. P. A.; TRAVASSOS DA ROSA, J. \& COSTA, C. D S. Estudos sorológicos para pesquisa de anticorpos ie arbovírus em população humana da região do Vale do Ribeira. III. Inquérito em coabitantes com casos de encefalite por Flavivirus Rocio. Rev. Saúde públ. (S. Paulo), 16: 160-170, 1982.

14. IVERSSON, L. B.; TRAVASSOS DA ROSA, A. P. A.; TRAVASSOS DA ROSA, J.; PINTO, G. H. \& MACEDO. O. - Estudos sorológicos para pesquisa de anticorpos de arbovirus em população humana da regiăo do Vale do Ribeira. IV. Inquérito em escolares residentes no Municipio de Iguape, SP (Brasil). Rev. Saúde pf́bl. (S. Paulo), 17: 423-435, 1983.

15. LOPES, O. DE S.; COIMBRA, T. L. M.; SACCHETTA, L. DE A. \& CALISHER, C. H. - Emergence of a nep arbovirus disease in Brazil. I - Isolaion and characterization of the etiologic agent, Rocio virus. Amer. J. Epidem., 107: 444-449, 1978.

16. LOPES, O. DE S.; SACCHETTA, L. DE A.; COIMBR T. L. M.; PINTO, G. H. \& GLASSER, C. M. - Emerarbovirus disease in Bratil. I - Isolation and charac. miologic studies on 1975 epidemic. Amer. J. Epidem., 168: 394-401, 1978.

17. LOPES, O. S.; SACCHETTA, L. DE A.; COIMBRA, T. L. M.; PINTO, G. A. \& CLASSER, C. M. - Emergence of a new arbovirus disease in Brazil. III. Isolation of Rocio virus from Psorophora ferox (Humboldt, 1819). Amer. J. Epidem., 113: 122-125, 1981.

18. METSELAAR, D. - Isolation of arbovirus Group A and Group $C$ in Surinam. Trop. geogr. Med., 18: 137. $142,1966$.

19. MITCHELL, C. J.; MONATH, T. P. \& CROPP, E. B. - Experimental transmission of Rocio virus by mosquitoes. Amer. J. trop. Med. Hyg., 30: 465-472, 1981.

20. MITCHELL, C. J. \& FORATTINI, O. P. - Experimental transmission of Rocio encephalitis virus by Aedes scapularis (Diptera: Culicidae) from the epidemic zone in Brazil. J. med. Entomol., 21:: 34-37, 1984.

21. MONATH, T. P.; KEMP, G. E.; CROPP, C. B. \& BOWEN, G. S. - Experimental infection of hotuse, sparrows (Passer domesticns) with Rocio virus. Amer. J. trop. Med. Hyg., 27: 1251-1254, 1978.

22. SECRETARIA DE ECONOMIA E PLANEJAMENTO Conheça sed município, Regiâo do Vale do Rlbeira. Sāo Paulo, 1974. v. 1.

23. SHOPE, R. E. - The use of micro-hemagglutination - inhibition test to follow antibody response after arthropod-borne virus infection in a community of forest animals. An. Microbiol. (Rio de J.), 11: 167-171. 1983. 
IVERSSON, L. B.; TRAVASSOS DA ROSA, A. P. A.; COIMBRA, T. I. M.; FERRERA, I. B. \& NASSAR, E. da S. - Hu. man disease in Ribeira Valley, Brazil caused by Caraparu, a group $\mathrm{C}$ arbovirus - Report of a case. Rev. Inst. Med. trop. São Paulo, 29:112-117, 1987.

24. SHOPE, R. E. \& CAUSEY, O. R. - Further studies on the serological relationship of Group $\mathrm{C}$ arthropod-borne virus and the application of these relationships to ra. pid identification of types. Amer. J. trop. Med. Hyg., 11: $283-290,1962$.

25. TIRIBA, A. DA C.; MIZIARA, A. M.; LOURBNCO, R.; COSTA, C. DA S. \& PINTO, G. H. - Encefalite humana primária epiđêmica por arbovírus observada no litoral sul do Estado de São Paulo. Rev. Ass. méd. bras. 22: 415-422, 1976 .

Recebldo para publicacåa em 29/8/86. 